\title{
MAPPING OF THE BRAZILIAN SCIENTIFIC PUBLICATION ON FACILITY LOCATION
}

\author{
Vanessa de Almeida Guimarães ${ }^{1,2 *}$, Glaydston Mattos Ribeiro ${ }^{2}$ \\ and Maxwel de Azevedo-Ferreira ${ }^{3}$
}

Received July 7, 2017 / Accepted May 16, 2018

\begin{abstract}
Mathematical models are relevant to indicate the optimal location of facilities and, consequently, help in the search for efficiency in the supply chain. Although facility location problems are consolidated in the Operational Research field, few publications are dedicated to investigate the profile of the academic production (the amount of paper published), aiming to direct new studies on the subject and propose models that solve the current challenges. Thus, this paper aims to present a scientometric analysis of the articles on facility location published in the Web of Science, in order to verify the profile of Brazilian scientific production. As result, approximately $2 \%$ of the papers have researchers affiliated to Brazilian institutions. The interest for the subject is recent, with emphasis on universities. Brazil maintains an intense international collaboration network, cooperating with 45 different countries, especially USA. Finally, there is opportunity for publications that include the environmental dimention to mathematical models and for expansion in company-university-government collaboration.
\end{abstract}

Keywords: facility location, operational research, logistics, Brazil, scientometry.

\section{INTRODUCTION}

The low efficiency of the Brazilian transport sector is due, among other factors, to its high logistics cost - which varies from $10.6 \%$ to $15 \%$ of Gross Domestic Product - GDP, while the United States registers $8.5 \%$ (CNT, 2014). As a result, different government programs, such as the National Logistics and Transport Plan - PNLT (MT, 2007, 2009, 2012), State Plan of Logistics of Cargo of the State of Rio de Janeiro - PELC/RJ (Government of Rio de Janeiro, 2013) and the Strategic Plan for Logistics and Transport of the State of Espírito Santo - PELT/ES (Government of Espírito Santo, 2009), indicate the need for the installation of integration terminals.

\footnotetext{
*Corresponding author.

${ }^{1}$ Centro Federal de Educação Tecnológica Celso Suckow da Fonseca - CEFET/RJ. Rua do Areal, 522, Sala 4D, Parque Mambucaba, 23953-030 Angra dos Reis, RJ, Brazil. E-mail: vanessa.guimaraes@ cefet-rj.br

${ }^{2}$ Programa de Engenharia de Transportes - COPPE/UFRJ. Cidade Universitária, Centro de Tecnologia, Bloco H, sala 111, Caixa Postal 68511, 21941-972 Rio de Janeiro, RJ, Brazil. E-mail: glaydston@ @et.coppe.ufrj.br

${ }^{3}$ IFRJ - Av. Pref. Botafogo, Comercial, 27541-030 Resende, RJ, Brazil. E-mail: maxwel_ferreira@hotmail.com
} 
These terminals would be essential to achieve the rebalancing of the transport matrix and, consequently, the reduction of logistics costs and the increase of competitiveness of the country's economy (Guimarães et al., 2017ab). Thus, location models appropriate to the Brazilian context would become relevant to achieve the government goals stablished for the transport sector.

In this context, it becomes relevant to understand the profile of academic research about facilities location, in order to direct future studies to fill the main gaps on the subject, as well as to understand the main areas of interest and how the collaboration network is configured between authors and organizations. This could facilitate the exchange of information and the establishment of partnerships for joint studies, especially to solve specific problems in the Brazilian context.

Thus, the following problem arises: what is the dynamics of the Brazilian scientific production (the amount of paper published) related to facility location models? Therefore, this paper aims to present a scientometric analysis of the articles about facility location, published in Web of Science, in order to verify the profile of the Brazilian scientific production of this area. As specific objectives, we intend to: (i) present the evolution of the Brazilian publications regarding this theme, identifying the main authors and organizations; (ii) identify the collaboration network among authors, organizations and countries related to Brazilian publications; and (iii) identify the importance of the facility location theme to transportation area, in the Brazilian context. For that, descriptive statistics techniques were applied, together with Scientometry and Social Network Analysis (SNA), as described in Section 3.

The article is divided into four more sections after this introduction: (i) discussion of location problems; (ii) description of the methodological procedures; (iii) presentation and discussion of the results; and (iv) final considerations.

\section{LOCATION PROBLEMS}

The facility location problems are consolidated in the Operational Research literature (Melo, Nickel \& Saldanha da Gama, 2009), attracting researchers' interest due to their various applications (Ulukan \& Demircioglu, 2015) in the public, private, military and/or business areas, nationally and internationally (Farahani, SteadieSeifi \& Asgari, 2010). Table 1 summarizes different studies that address this theme, showing the different types of problems studied as well as the types of facility to be located.

In Table 1, we verify facilities dedicated to the freight transportation (such as intermodal terminals and hubs), as well as facilities for the citizen (such as health services and parking lots). The types of problems also range from simple linear location and/or allocation problems to capacitated, multiperiod and multilayer ones (among others).

Regarding the freight transportation, it is understood that the theme "facility location" is fundamental either to the success of intermodal transport (SPNT, 2016; Guimarães et al., 2017ab) or for the efficiency of the supply chain (Melo, Nickel \& Saldanha da Gama, 2009). The location can impact in travel times, cost, service level, coverage, among other factors that can be optimized by mathematical models. In this context, Table 2 presents papers about facility location that survey the main models in the literature including, in some cases, solution methods. 
Table 1 - Studies about facility location.

\begin{tabular}{|c|c|c|}
\hline Author & Type of problem & Facility to be located \\
\hline Abyazi-Sani \& Ghanbari (2016) & Hub location problem & Hubs \\
\hline Alizadeh et al. (2015) & Location-allocation problem $^{1}$ & Facilities (e.g. vehicle agency) \\
\hline Alumur, Yaman \& Kara (2012) & Hub location problem ${ }^{2}$ & Hubs \\
\hline Ardjmand et al. (2016) & $\begin{array}{l}\text { Transportation, location and } \\
\text { allocation problem }\end{array}$ & $\begin{array}{l}\text { Disposal facilities for } \\
\text { hazardous materials }\end{array}$ \\
\hline $\begin{array}{l}\text { Correia, Nickel \& } \\
\text { Saldanha-da-Gama (2017) }\end{array}$ & Hub location problem ${ }^{3}$ & Hubs \\
\hline $\begin{array}{l}\text { Coutinho-Rodrigues, Tralhão \& } \\
\text { Alçada-Almeida (2012) }\end{array}$ & Locating/routing problem & Shelters for evacuation plans \\
\hline Frade \& Ribeiro (2015) & Maximum coverage problem & Bike-sharing stations \\
\hline Fredriksson (2016) & $p$-Median problem & Citizen service centers \\
\hline $\begin{array}{l}\text { Gelareh, Monemi \& } \\
\text { Nickel (2015) }\end{array}$ & $\begin{array}{l}\text { Hub location problem with } \\
\text { budget constraints } 4\end{array}$ & Hubs \\
\hline Guimarães et al. (2017a) & Location-allocation problem & Integration logistic centers \\
\hline Guimarães et al. (2017b) & Location-allocation problem & Integration logistic centers \\
\hline Hajipour et al. (2016) & Location-allocation problem 5 & Multi-layer facilities \\
\hline Hamadani et al. (2013) & Location-allocation problem & Parkings \\
\hline $\begin{array}{l}\text { Harris, Mumford \& } \\
\text { Naim (2014) }\end{array}$ & Location-allocation problem & Facilities (e.g. depots) \\
\hline He et al. (2015) & Hub location problem & Intermodal hubs \\
\hline Ishfaq \& Sox (2011) & Hub location-allocation problem & Intermodal hubs \\
\hline Lin, Chiang \& Lin (2014) & Location problem & $\begin{array}{l}\text { Intermodal terminals } \\
\text { (e.g. container terminals) }\end{array}$ \\
\hline Lin \& Lin (2016) & Location problem & $\begin{array}{l}\text { Intermodal terminals } \\
\text { (e.g. container terminals) }\end{array}$ \\
\hline $\begin{array}{l}\text { Meisel, Krischtein \& } \\
\text { Bierwith (2013) }\end{array}$ & Intermodal transportation planning & $\begin{array}{l}\text { Intermodal netword } \\
\text { (road and rail) }\end{array}$ \\
\hline Menezes \& Pizzolato (2014) & $p$-median and maximal covering & Public schools \\
\hline Ozceylan et al. (2017) & $p$-Median and set covering problem & Health services \\
\hline Pamucar et al. (2016) & Green $p$-median problem & Urban logistic terminals \\
\hline Paul \& MacDonald (2016) & Location-allocation problem & Distribution centers \\
\hline $\begin{array}{l}\text { Santos, Limbourg \& } \\
\text { Carreira (2015) }\end{array}$ & Location-allocation problem & Inland intermodal terminals \\
\hline Upchurch \& Kubyb (2010) & $\begin{array}{l}p \text {-Median problem and } \\
\text { flow-refueling model }\end{array}$ & Fuel stations \\
\hline Wen et al. (2015) & Location-allocation problem $^{6}$ & Facilities (e.g. warehouses) \\
\hline Yu et al. (2013) & Covering problem & Transit hubs \\
\hline $\begin{array}{l}\text { Zahiri, Tavakkoli-Moghaddam \& } \\
\text { Pishvaee (2014) }\end{array}$ & Location-allocation problem & Health services \\
\hline Zhang et al. (2016) & Location-allocation problem & Health services \\
\hline Zu et al. (2016) & Location-allocation problem & Health services \\
\hline
\end{tabular}

Note: (1) Capacitated multi-facility; (2) Hierarchical multimodal; (3) Stochastic multi-period capacitated multiple allocation; (4) Multi-period uncapacitated multiple allocation; (5) Multi-objective multi-layer facility; (6) Capacitated. 
Table 2 - Papers about facility location surveys.

\begin{tabular}{|c|c|}
\hline Author & Paper description \\
\hline Alumur \& Kara (2008) & $\begin{array}{l}\text { They review the literature on hub location models published } \\
\text { from } 1990 \text { to } 2001 \text {. }\end{array}$ \\
\hline Arabani \& Farahani (2012) & $\begin{array}{l}\text { They present an overview of classifications and applications } \\
\text { of location problems, discussing the main static (covering and } \\
\text { center problems, for example) and dynamic models (such as } \\
\text { location-reallocation and time-dependent problems). }\end{array}$ \\
\hline Campbell \& O’Kelly (2012) & $\begin{array}{l}\text { They analyze the evolution of studies in this area, from } 1986 \text { to } \\
2011 \text {. }\end{array}$ \\
\hline Crainic \& Laporte (1997) & $\begin{array}{l}\text { They present the transport planning models applied to differ- } \\
\text { ent levels (strategic, tactical and operational), including location } \\
\text { models. }\end{array}$ \\
\hline Eskandarpour et al. (2015) & $\begin{array}{l}\text { They provide a literature review of papers about supply chain } \\
\text { network design, involving mathematic models of coverage that } \\
\text { include economic, environmental and/or social factors. }\end{array}$ \\
\hline $\begin{array}{l}\text { Farahani, SteadieSeifi \& } \\
\text { Asgari (2010) }\end{array}$ & $\begin{array}{l}\text { They analyze multicriteria location problems (biobjective, mul- } \\
\text { tiobjective and multi-attribute) and their solution methods. }\end{array}$ \\
\hline Farahani et al. (2012) & $\begin{array}{l}\text { They present a literature review specific of covering problem } \\
\text { models. }\end{array}$ \\
\hline Farahani et al. (2013) & $\begin{array}{l}\text { They update the paper written by Alumur \& Kara (2008) by } \\
\text { analyzing, specifically, the studies about hub location problem } \\
\text { published from } 2007 \text { (including the application of exact, heuris- } \\
\text { tics and metaheuristics methods). }\end{array}$ \\
\hline Klose \& Drexl (2005) & $\begin{array}{l}\text { They survey the facility location studies, contrasting continuous } \\
\text { and discrete, capacitated and uncapacitated, single-source and } \\
\text { multiple-souce, static and dynamic models. }\end{array}$ \\
\hline $\begin{array}{l}\text { Melo, Nickel \& } \\
\text { Saldanha-da-Gama (2009) }\end{array}$ & $\begin{array}{l}\text { They analyze papers about location-allocation applied to the lo- } \\
\text { gistics context, especially the supply chain. }\end{array}$ \\
\hline
\end{tabular}

Table 2 shows papers dedicated to studying some classic models of facility location and in the later innovations presented in recent researches. However, only Eskandarpour et al. (2015) map the evolution of scientific production, although they do not focus on the specific analysis of location models (but on the design of the supply chain).

In this same context, Liu \& Gui (2016) aims to understand the evolution of research in the Transport Geography area by investigating its scientific production (as proposed in this paper for the "location" theme). It was the only paper focusing in the transport area that applies a methodology similar to one performed in the present paper.

Therefore, the study proposed here is relevant because it helps to understand the positioning of researchers affiliated to Brazilian institutions regarding the study of the main topics of interest in the area as well as the collaboration network that they maintain with international researchers. 
We believe that it would allow the expansion of Brazilian scientific production, as well as the identification of possible partnerships to deal with the recent challenges of the area, e.g. the incorporation of the social and environmental dimensions aiming at achieving sustainability, as pointed out in Arabani \& Farahani (2012) and in Farahani et al. (2013).

\section{METHODOLOGICAL PROCEDURES}

We adopted a quantitative approach, using statistical methods allied to Scientometrics and Social Network Analysis (SNA). Scientometrics aims to understand the structure, evolution and connections of a given area or field of study, thus establishing relations between science and technological, economic and social development (Gregolin et al., 2005).

The SNA methodology allows identifying the importance or prominence of the actors of a social network, as well as degrees of closeness between documents and collaboration among authors (Guimarães et al., 2011). In order to identify the scientific production related to facility location topic, the articles registered in the Web of Science were analyzed. This database was chosen for having a satisfactory scope and coverage (Chen, 2010). In this context, the scientometric analysis followed the steps presented in Figure 1.

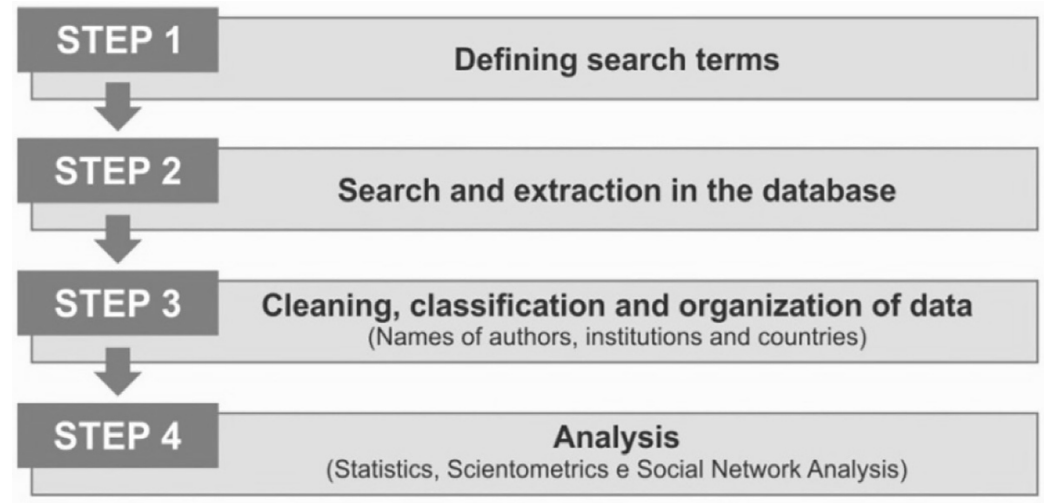

Figure 1 - Steps of the research.

It should be noted that, in Step 1, the most adequate search terms were defined through a preliminary research in the papers considered as "benchmark" in this theme (presented in Section 2). The keywords selection may influence the results of the search, then, it is a crucial step. Therefore, the terms used, as well as the details for the search and extraction of the database (Step 2), are explicit in Table 3.

Step 3 involved a refinement of the selection and organization of the database. We emphasize that some papers might be let aside, if their keywords do not match to those searched in the database. Vantage Point data mining software (The Vantage Point, 2016) was used in Step 3, while for Step 4 the UCinet (Borgatti, Everett \& Freeman, 2002) was applied. Table 4 summarizes the criteria analyzed in Step 4, while Section 4 presents the main results obtained with the search. 
Table 3 - Description of the search strategy.

\begin{tabular}{|c|c|}
\hline Criteria & Description \\
\hline Topic $^{1}$ & $\begin{array}{l}\text { TS = ("facilit* locatio*” OR "hub* locatio*” OR " } p \text {-median" OR "set } \\
\text { covering proble*” OR " } p \text {-cent*" OR "maximal cover*”) AND CU = } \\
\text { ("Brasil" OR "Brazil") }\end{array}$ \\
\hline Database & Web of Science \\
\hline Indexes & 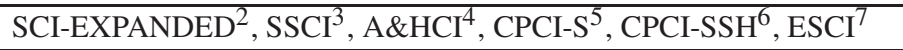 \\
\hline Coverage time & All years until 2017 \\
\hline Data refinement & $\begin{array}{l}\text { None, which means that the search considered the publications of all } \\
\text { areas registered in the Web of Science }\end{array}$ \\
\hline Date of search & April 20th, 2018, at 9:30 a.m. \\
\hline
\end{tabular}

Notes: (1) TS = Topic, which means the words that will be searched in in the titles, abstracts and keywords of articles. $\mathrm{CU}=$ country. Note that when searching for "CU", we define the paper must have, at least, one author affiliate to the specified country. Therefore, combining "TS AND CU" we gather the articles about the theme published by authors filiated to Brazilian organizations; (2) Science Citation Index Expanded (SCIEXPANDED) covers more than 8,300 journals in 150 different areas, with publications from 1990. (3) Social Sciences Citation Index (SSCI) focus in social sciences, covering 2,950 publication sources, in over 50 areas, since 1990. (4) Arts \& Humanities Citation Index (A\&HCI) is a citation index of Arts and Humanities area, covering over 1,600 publication sources, since 1975. (5) It covers the conference proceeding literature of all technical and scientific fields. (6) It covers the conference proceeding literature of all fields of social science, arts and humanities. (7) Covering publications from 2015, this index contains records of articles in journals not covered by SCI-EXPANDED, SSCI and A\&HCI yet (Thomson Reuters, 2016).

Table 4 - Scientometrics indicators.

\begin{tabular}{l|l}
\hline \multicolumn{1}{c|}{ Indicator } & \multicolumn{1}{c}{ Description } \\
\hline Number of papers & Details the evolution of the publication year by year \\
\hline Co-autorship & Shows the degree of collaboration among authors \\
\hline $\begin{array}{l}\text { Maps of the scientific } \\
\text { fields and countries }\end{array}$ & $\begin{array}{l}\text { Helps to locate the relative positions of different countries in global } \\
\text { scientific cooperation, as well as the main areas that are interested in } \\
\text { the subject }\end{array}$ \\
\hline Keywords & $\begin{array}{l}\text { Allows to identify the main terms associated to the given search, as well } \\
\text { as the evolution of the terms over the years }\end{array}$ \\
\hline
\end{tabular}

\section{DISCUSSION OF FINDINGS}

From the search made in the Web of Science database, we verified that only 192 publications ( $2.3 \%$ of the total scientific production on "facility location") were developed by Brazilian researchers or for foreign researchers in partnership with Brazilian organizations. Although it seems to be a low percentage, Brazil is among the 15 most important countries, considering the database as role, with volume of publication superior to developed countries as Portugal and Switzerland. Figure 2 shows the evolution of publications about this theme. 


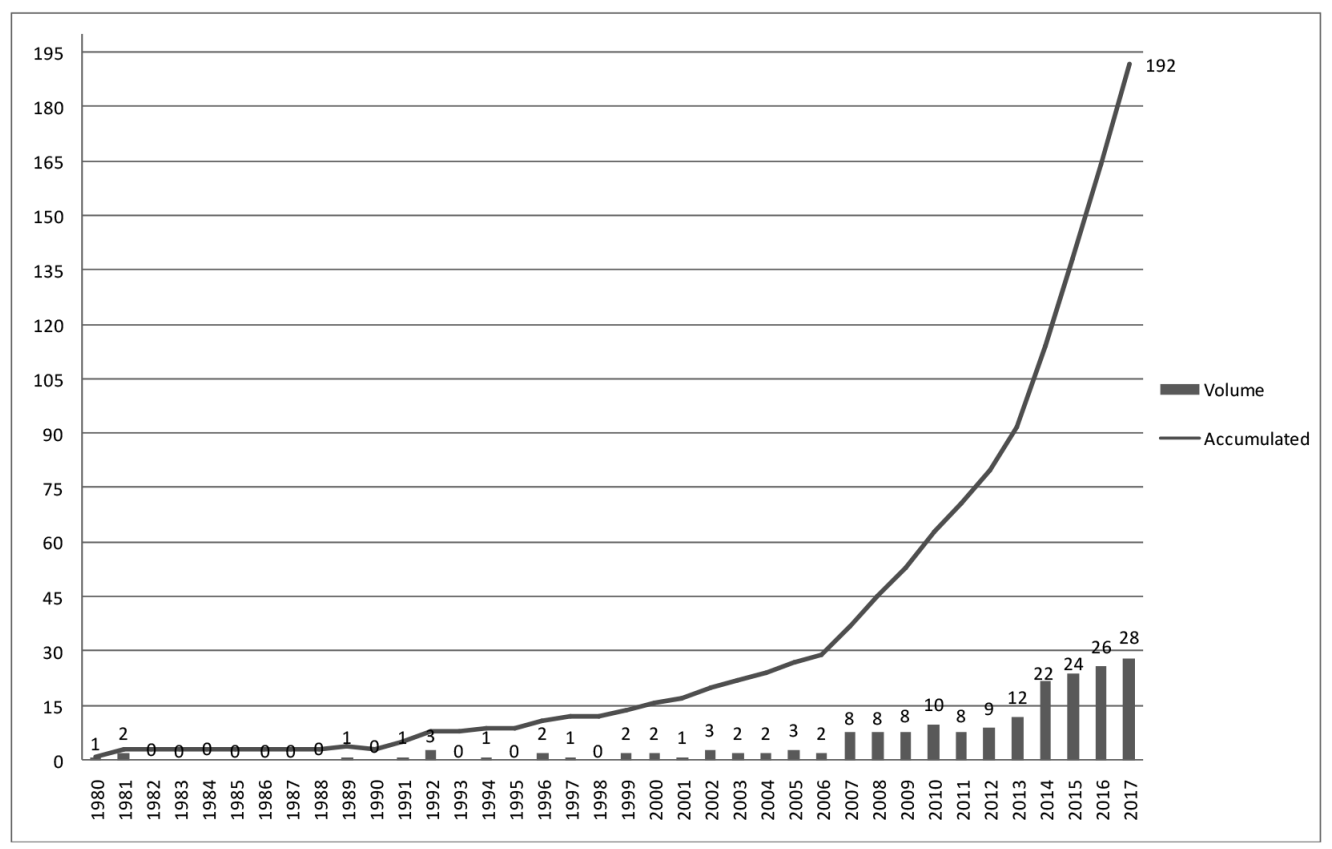

Figure 2 - Evolution of publications about facility location - Brazilian context.

We verify that the first publication was registered in 1980 (12 years after the first international publication), but there was a constancy in publications only from 1999. There is an increase in interest on the topic since 2007. Although the Brazilian production in 2017 represents only approximately $0.34 \%$ of all international publications and $4.16 \%$ in 2017 , this is the largest representation since 1989 when the international publication on the theme was restricted to 22 articles (of which $4.55 \%$ were Brazilian). Besides, the curve represents the crescent interest about the theme over the years.

Regarding the main authors, Table 5 presents those whose publication volume is, at least, equal to three papers. It should be noted that, approximately 1,400 authors are listed in publications that have, at least, one author affiliated to Brazilian institutions.

Regarding the main organizations, Figure 3 indicates that interest in the subject is predominantly academic (74.6\%). However, government and corporate institutions represent $13 \%$ and $6 \%$ of publications, respectively. Table 6 presents the main organizations, whose publications are equal to or greater than five papers.

We verified that four universities located in the southeast of the country are in the first places, and only UFMG is mentioned in $18.8 \%$ of articles with Brazilian affiliation. Of the eighteen institutions, ten are located in the Southeast, two in the South, two in the Northeast and one in the Midwest, while three are international organizations in cooperation with Brazilian institutions. Besides, among them, there are thirteen universities which emphasize the greater interest of 
Table 5 - Main authors related to papers filiated to Brazilian organizations.

\begin{tabular}{|c|c|c|c|}
\hline $\mathrm{P}^{(1)}$ & Author & Number of papers & $\mathrm{B}^{(2)}$ \\
\hline $1^{\mathrm{st}}$ & de Camargo RS & 12 & $6.3 \%$ \\
\hline \multirow{2}{*}{$2^{\text {nd }}$} & de Miranda G & 11 & $5.7 \%$ \\
\hline & Lorena LAN & 11 & $5.7 \%$ \\
\hline $3^{\text {rd }}$ & Galvão RD & 9 & $4.7 \%$ \\
\hline $4^{\text {th }}$ & Miyazawa FK & 8 & $4.2 \%$ \\
\hline $5^{\text {th }}$ & Resende $\mathrm{MGC}^{(3)}$ & 7 & $3.6 \%$ \\
\hline $6^{\text {th }}$ & Ribeiro GM & 6 & $3.1 \%$ \\
\hline \multirow{6}{*}{$7^{\text {th }}$} & Steiner MTA & 5 & $2.6 \%$ \\
\hline & Guimarães FG & 5 & $2.6 \%$ \\
\hline & Mateus GR & 5 & $2.6 \%$ \\
\hline & $\mathrm{O}^{\prime}$ Kelly ME $\mathrm{ME}^{(3)}$ & 5 & $2.6 \%$ \\
\hline & Pedrosa LLC & 5 & $2.6 \%$ \\
\hline & Ribeiro CC & 5 & $2.6 \%$ \\
\hline \multirow{4}{*}{$8^{\text {th }}$} & Aloise D & 4 & $2.1 \%$ \\
\hline & Camponogara E & 4 & $2.1 \%$ \\
\hline & Luna HP & 4 & $2.1 \%$ \\
\hline & Santos AC & 4 & $2.1 \%$ \\
\hline \multirow{13}{*}{$9^{\text {th }}$} & Campbell JF(3) & 3 & $1.6 \%$ \\
\hline & Chaves AA & 3 & $1.6 \%$ \\
\hline & Constantino AA & 3 & $1.6 \%$ \\
\hline & de Almeida AT & 3 & $1.6 \%$ \\
\hline & de Andrade CE & 3 & $1.6 \%$ \\
\hline & de Sá EM & 3 & $1.6 \%$ \\
\hline & Guersola MS & 3 & $1.6 \%$ \\
\hline & Martins Ferreira Filho VJ & 3 & $1.6 \%$ \\
\hline & Meire LAA & 3 & $1.6 \%$ \\
\hline & Pessoa LS & 3 & $1.6 \%$ \\
\hline & Plucenio A & 3 & $1.6 \%$ \\
\hline & Santibanez-Gonzalez EDR & 3 & $1.6 \%$ \\
\hline & Wanke PF & 3 & $1.6 \%$ \\
\hline
\end{tabular}

Notes: (1) P represents the position of the authors in the ranking; (2) B indicates the representativeness in relation to Brazilian production. The percentages are not cumulative, since the same paper might be signed by different researchers; (3) It is related to authors (Brazilian or not) affiliated to foreign universities who have developed works in partnership with Brazilian researchers.

academics, shown in Figure 3. We highlight that two of them are foreign universities, which indicates the international cooperation and its importance tothe national scientific production. In addition, there is only one (foreign) company and one governmental organization among the main institutions. 


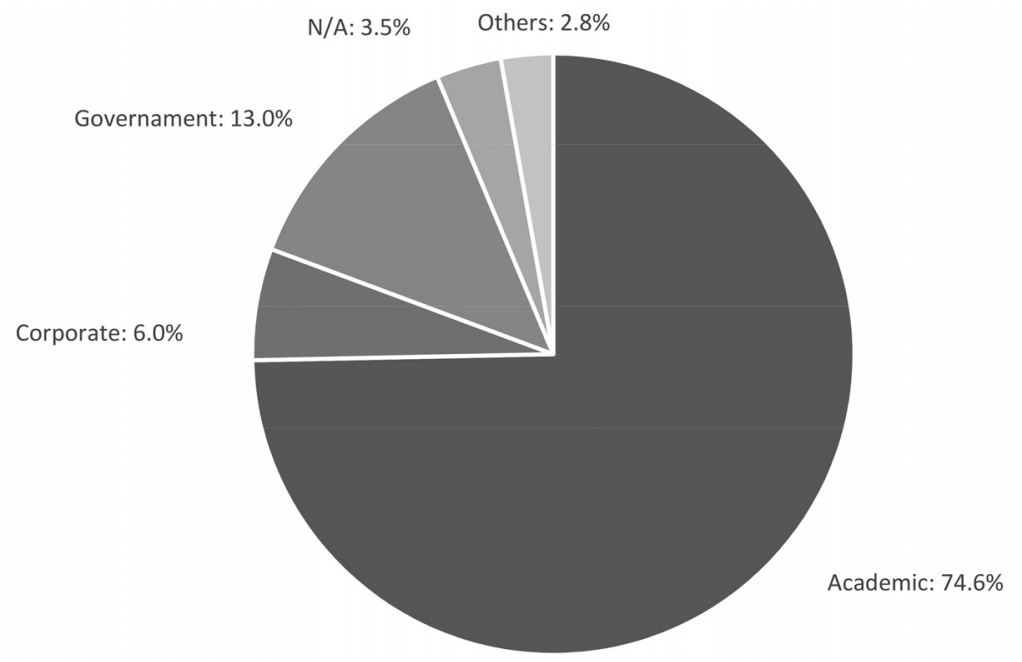

Figure 3 - Distribution of the Brazilian publication by type of organization. Notes: "Others" are mainly related to international research institutes (as Conseil Européen pour la Recherche Nucléaire - CERN), but also include organizations that do not belong to other categories. "N/A" represets those that we could not identify the type (or whose registers were wrong, e.g. part of an address instead of the institutions' name).

Table 6 - Eighteen organizations with greater volume of publication.

\begin{tabular}{c|c|c|c|c}
\hline Position & Organizations & Location & Number of papers & B \\
\hline $1^{\text {st }}$ & Univ. Fed. Minas Gerais - UFMG & Southeast & 36 & $18.8 \%$ \\
\hline $2^{\text {nd }}$ & Univ. Fed. Rio de Janeiro - UFRJ & Southeast & 24 & $12.5 \%$ \\
\hline $3^{\text {rd }}$ & Univ. São Paulo - USP & Southeast & 18 & $9.4 \%$ \\
\hline $4^{\text {th }}$ & Univ. Estadual Campinas - UNICAMP & Southeast & 17 & $8.9 \%$ \\
\hline $5^{\text {th }}$ & Univ. Fed. Santa Catarina - UFSC & South & 13 & $6.8 \%$ \\
\hline $6^{\text {th }}$ & Univ. Fed. Fluminense - UFF & Southeast & 11 & $5.7 \%$ \\
\hline $7^{\text {th }}$ & Natl. Inst. Space Res. - INPE & Southeast & 10 & $5.2 \%$ \\
\hline $8^{\text {th }}$ & Univ. Estadual Paulista - UNESP & Southeast & 9 & $4.7 \%$ \\
\hline \multirow{2}{*}{$9^{\text {th }}$} & Univ. Fed. Goiás - UFG & Midwest & 7 & $3.6 \%$ \\
\cline { 2 - 5 } & Univ. Fed. Ouro Preto - UFOP & Southeast & 7 & $3.6 \%$ \\
\hline \multirow{3}{*}{$10^{\text {th }}$} & AT\&T Labs. Res. & International & 6 & $3.1 \%$ \\
\cline { 2 - 5 } & Ohio State Univ. & International & 6 & $3.1 \%$ \\
\cline { 2 - 5 } & São Paulo Fed. Univ. - UNIFESP & Southeast & 6 & $3.1 \%$ \\
\hline \multirow{4}{*}{$11^{\text {th }}$} & Pontifícia Univ. Católica Parana - PUC-PR & South & 5 & $2.6 \%$ \\
\cline { 2 - 5 } & Pontifícia Univ. Católica Rio de Janeiro - PUC-RJ & Southeast & 5 & $2.6 \%$ \\
\cline { 2 - 5 } & Univ. Fed. Pernambuco - UFPE & Northest & 5 & $2.6 \%$ \\
\cline { 2 - 5 } & Univ. Fed. Rio Grande do Norte - UFRN & Northest & 5 & $2.6 \%$ \\
\cline { 2 - 5 } & Univ. Technol. Troyes & International & 5 & $2.6 \%$ \\
\hline
\end{tabular}

Note: (1) There were approximately 285 different organizations registered in Brazilian publications. The percentages are not cumulative, since an article can have the affiliation of researchers from different institutions. (2) B indicates representativeness in relation to Brazilian production. 
Thus, Figure 4 shows the countries with the largest joint publication with Brazil. First is USA with 35 joint papers, followed by United Kingdom with 14 and France with 12. Canada, Portugal and Germany have 8, 6 and 4 papers, respectively. China, Italy, Netherlands, Spain and Sweden have three joint articles, each; while Austria, Ecuador, India, Japan, Mexico, Norway, Russia, South Korea and Switzerland have two publications each.

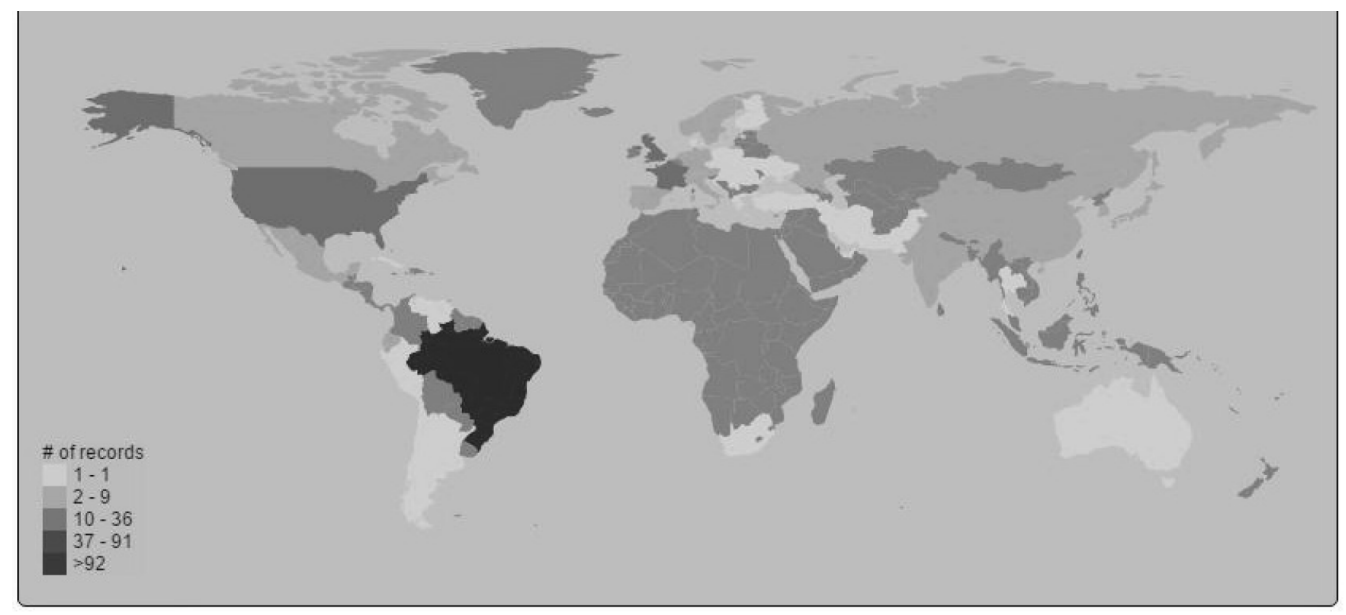

Figure 4 - Mapping of the intensity of Brazilian scientific production in international publications. Note: We highlight that nine papers did not have the country registrated in the database.

Besides, Figure 5 indicates the entire Brazilian network of relationships, involving 45 different countries. Once the evolution of Brazilian scientific production has been identified, as well as the main authors, organizations and countries that relates with the country, it is possible to verify the relations and cooperation network between authors, universities and countries. Figure 6 shows the collaboration network of the 88 authors with the highest publication volume (among those with at least 2 papers, each).

In Figure 6, it is possible to verify two consolidated networks, where one is formed by the two main authors (Miranda G and Camargo RS) and eight other researchers (including foreigners such as O'Kelly ME, Thizi JM and Campbell JF). It is noteworthy that the relationship between the two main authors is strong, and the 11 published papers have both listed in the authorship, explaining why they are the Brazilian references in the area. This network is well connected (although it is composed by fewer authors than the other one), since each researcher has connections with, at least, three other authors (except Thizi JM and Mateus GR).

The second consolidated network is formed by the authors with $2^{\text {nd }}$ and $4^{\text {th }}$ largest volume of articles (Lorena LAN and Miyazawa FX, respectively) and twenty other researchers. Nevertheless, the main authors are not strong related to each other, since they are not co-autors in any paper (their connection is made indirectly through Hansen P). This network seems to be formed by two other smaller ones, one that has Lorena as the main node and another one that has Miyazawa FX 


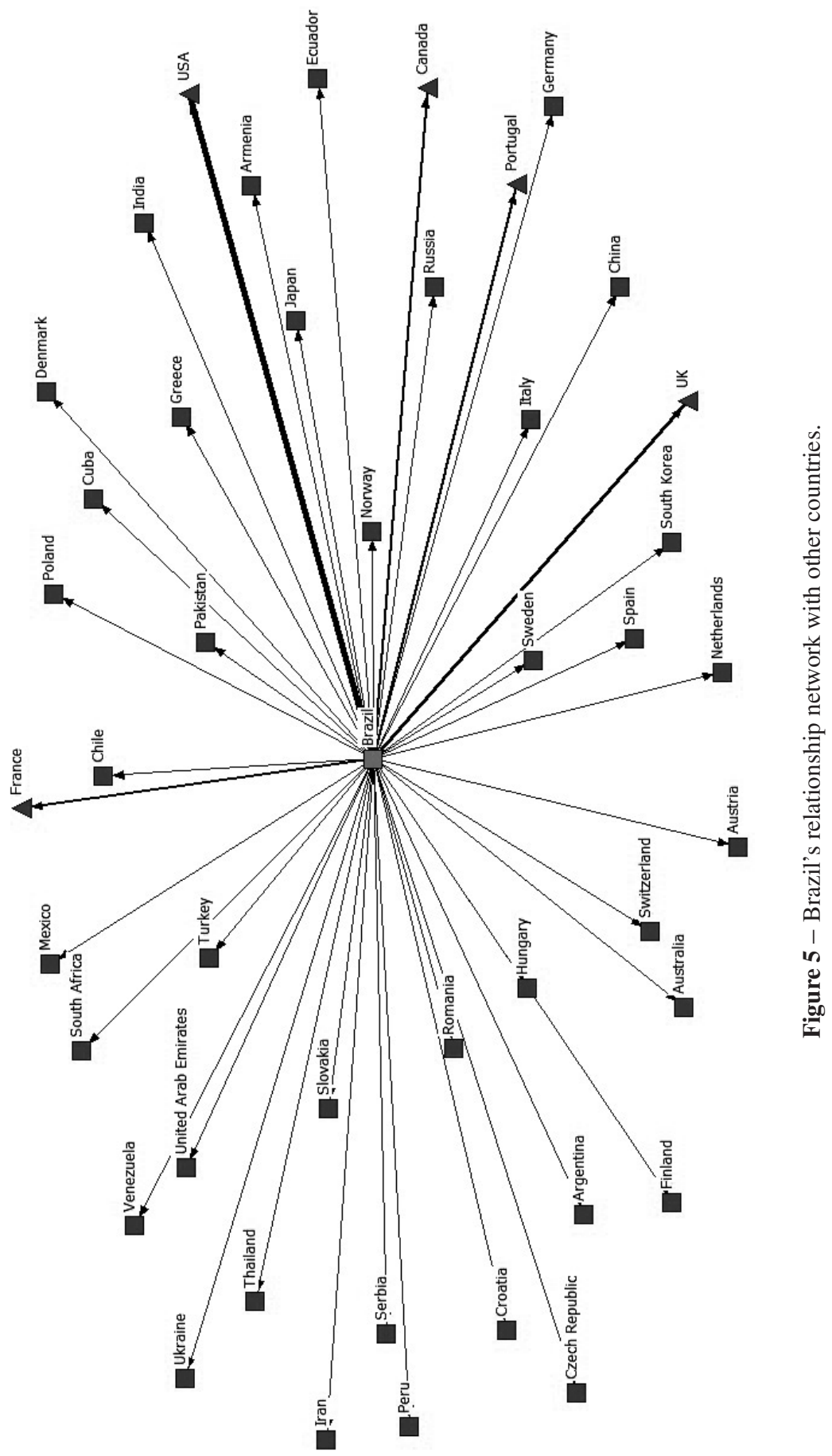

Pesquisa Operacional, Vol. 38(2), 2018 


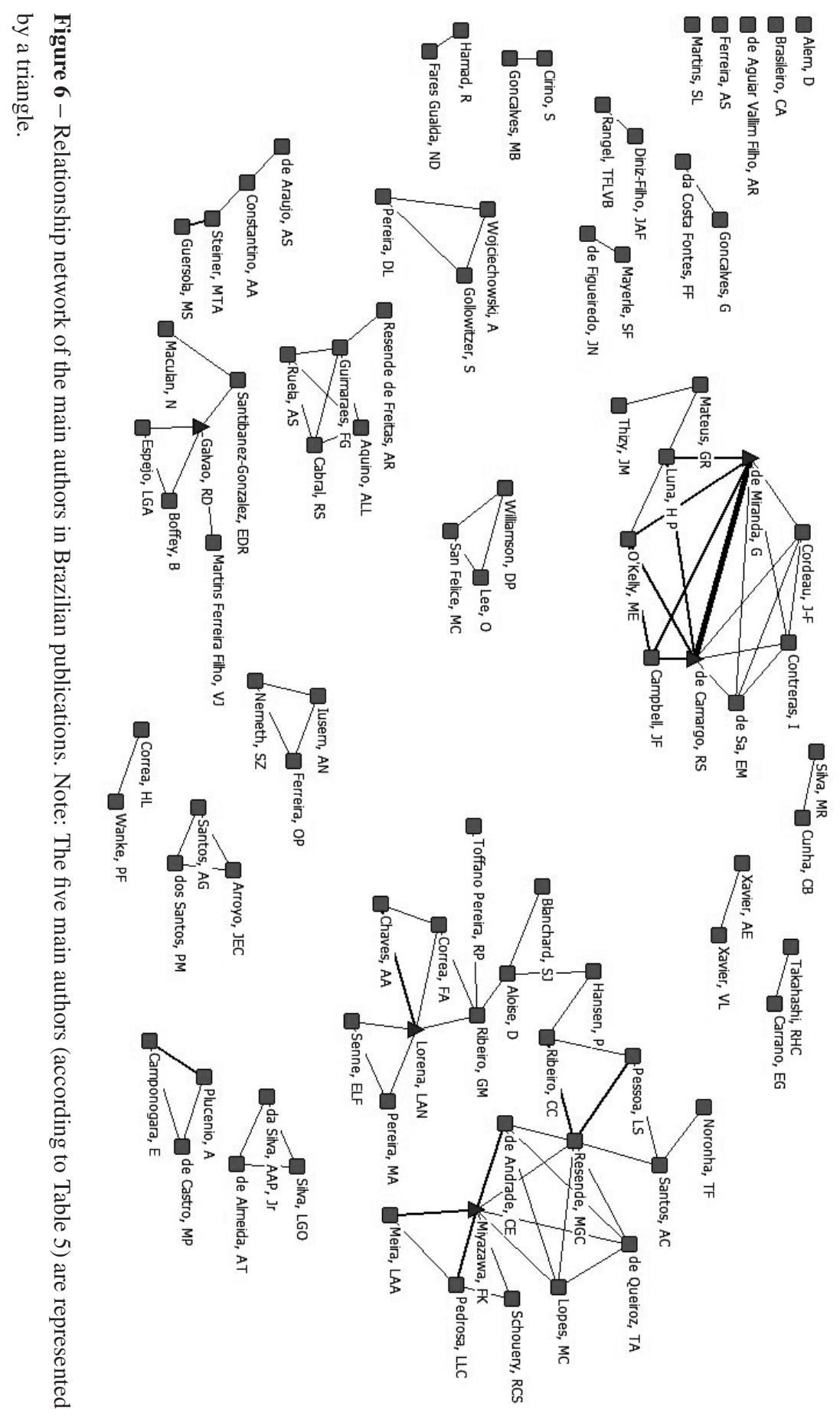

Pesquisa Operacional, Vol. 38(2), 2018 
as main researcher. Besides, every member is connected with, at least, two other researches (except Tofano Pereira RP, Blanchard SD and Noronha TF).

Lorena LAN keeps his stronger relationship with Chaves AA ( $9^{\text {th }}$ position in Table 5), while Miyazawa FX publishes the most with Pedrosa LLC, de Andrade CE and Meira LLA, respectively. In this network, we also can see Resende MGC and Ribeiro GM, $5^{\text {th }}$ and $6^{\text {th }}$ positions in Table 5. We highlight that it is also an international collaboration network because Resende MCG (despite being Brazilian) is not affiliated with a Brazilian organization.

Galvão RD, the $3^{\text {rd }}$ main author, is part of a low dense network, composed by other five authors. It is also an international network since Boffey B is filiated to an English university. There are also smaller collaboration networks composed of five, three or two collaborators and authors that do not belong to anyone.

Figure 7, on the other hand, presents the collaboration network of the 52 organizations with the highest volume of publication (with, at least, two papers each). It is verified that there is a dense and consolidated collaboration network that involves the academic institutions, as well as companies and government agency. From the first five organizations in Table 6, only UFSC is connected to just two institutions, one of them international (Univ. Technol. Troyes). There are also three universities that have no relationship with any other institution of this network: Univ. Fed. Rio Grande do Sul - UFRGS, Univ. Fed. Rural Semi Árido and Univ. Presbiteriana Mackenzie.

UFMG is one of the central nodes of this network, being connected to eitghteen organizations, ten of them foreing universities, one governamental agency and one company. It helps to explain its leadership in the volume of publication and show the level of internacionalization of the researches developed there. UFGM is strongly connected to Univ. Technol. Troyes, Ohio State Univ., Univ. Fed. Alagoas, UFOP and HEC Montreal.

Nevertheless, since that Figure 7 consolidates only the main organizations, we clarify that this university maintain more relationships than described in this figure. In addition, it can be seen that, from the five main organizations, only USP and UNICAMP are directly related. In this way, it is believed that there is more space for collaboration and, consequently, an increase in publications on the subject.

UFRJ, the $2^{\text {nd }}$ in the ranking, is connected to nine organizations, three of them international universities and one company. USP is linked to nine instituitions, four of them international. Besides, its strogly related to UNICAMP, the $4^{\text {th }}$ in the ranking. About UNICAMP, it is connected to ten organizations, two international companies and seven foreings universities.

About the type of organizations presented in the network, there are five companies (three national and two international): AT\&T, Amazon Com. Inc., Petrobras, Celpe and Embrapa. AT\&T has a strong relationship with UFF, UNICAMP and Amazon Com Inc, and is also connected to Univ. Fed. Pernambuco - UFPE, Univ. Fed. Rio Grande do Norte - UFRN, UFG and Rutgers State Univ. The variety and amount of connections help to understand why AT\&T is among the 


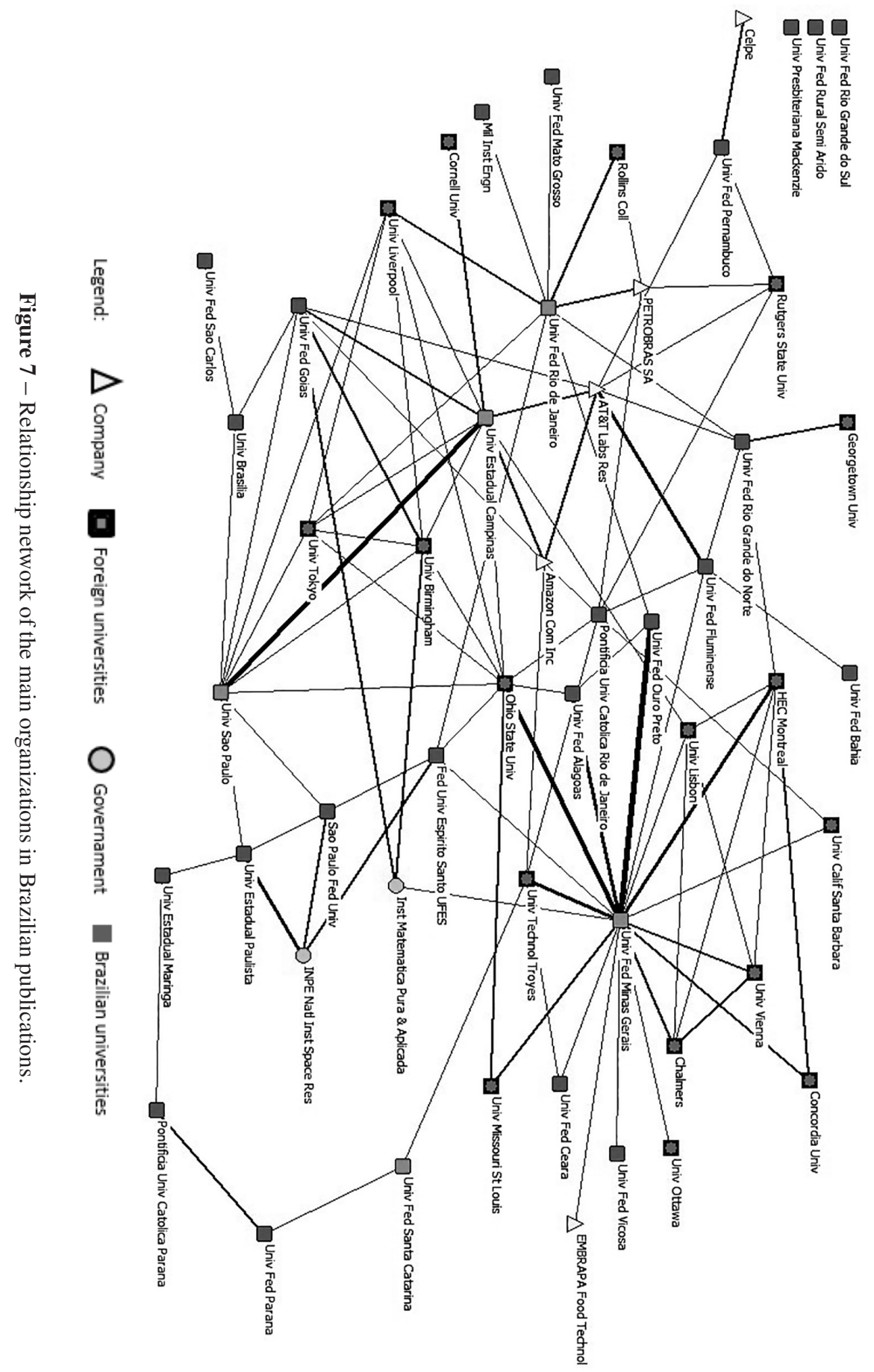

Pesquisa Operacional, Vol. 38(2), 2018 
main organizations (see Table 6). Amazon Com Inc, by its turn, is also connected to UNICAMP, PUC-RJ, UFG and Univ. Technol Troyes.

Petrobras is related to national (UFRJ and PUC-RJ) and international organizations (Rollins Coll and Rutgers State Univ.), while Embrapa is related only to UFMG and Celpe is connected only to UFPE. Regarding government organizations, only INPE and IMPA are presented in Figure 7. The former is connected to Univ. Espírito Santo - UFES, UNESP and UNIFESP; while the later is linked to UFG, Univ. Birmingham and UFMG.

It is noteworthy that the Top 4 organizations are related to, at least, three international institutions. It suggests that international cooperation is relevant to spread the scientific production of the area and justify the position of Brazil among the most relevant countries. Besides, three of the main universities are related to companies: UFMG with Embrapa, UFRJ with Petrobras and UNICAMP with AT\&T and Amazon. This demonstrates the interest in the "facility location" theme by different types of institution and reveals that partnership between the corporates, university and government can contribute to promote researches on the subject and to spread the scientific knowledge.

As for the main areas of interest (Table 7), we highlight publications in "Operations Research \& Management Science", "Computer Science", "Engineering and Business \& Economics", with more than 30 papers each. "Transportation" appears in $6^{\text {th }}$ position, with 12 records.

Table 7 - Main areas of interest in the theme facility location.

\begin{tabular}{c|c|c}
\hline Position & Research areas & Number of papers \\
\hline $1^{\text {st }}$ & Operations Research \& Management Science & 78 \\
$2^{\text {nd }}$ & Computer Science & 69 \\
$3^{\text {rd }}$ & Engineering & 59 \\
$4^{\text {th }}$ & Business \& Economics & 31 \\
$5^{\text {th }}$ & Mathematics & 24 \\
$6^{\text {th }}$ & Transportation & 12 \\
$7^{\text {th }}$ & Environmental Science \& Ecology & 11 \\
$8^{\text {th }}$ & Science \& Technology - Other Topics & 8 \\
\hline
\end{tabular}

In a complementary way, Figure 8 shows the evolution of the publication areas per year. "Operation Research \& Management Science" and "Business \& Economics" were the first areas with publication, in 1980; followed by "Transportation" in 1981. From 1982 to 1988 there is no record of publications involving researchers with Brazilian affiliation. Only in 1989, new publications were found in the area of "Operation Research \& Management Science". However, since 2007 , there has been an intensification of research on the subject, with diversification of areas of interest.

The leadership of "Operation Research \& Management Science" (presented in Table 7) can be explained by the constancy in publications when compared to "Transportation", for example, whose records date from 1981, 2008, 2009, 2014 to 2017, being the largest volume reached in 


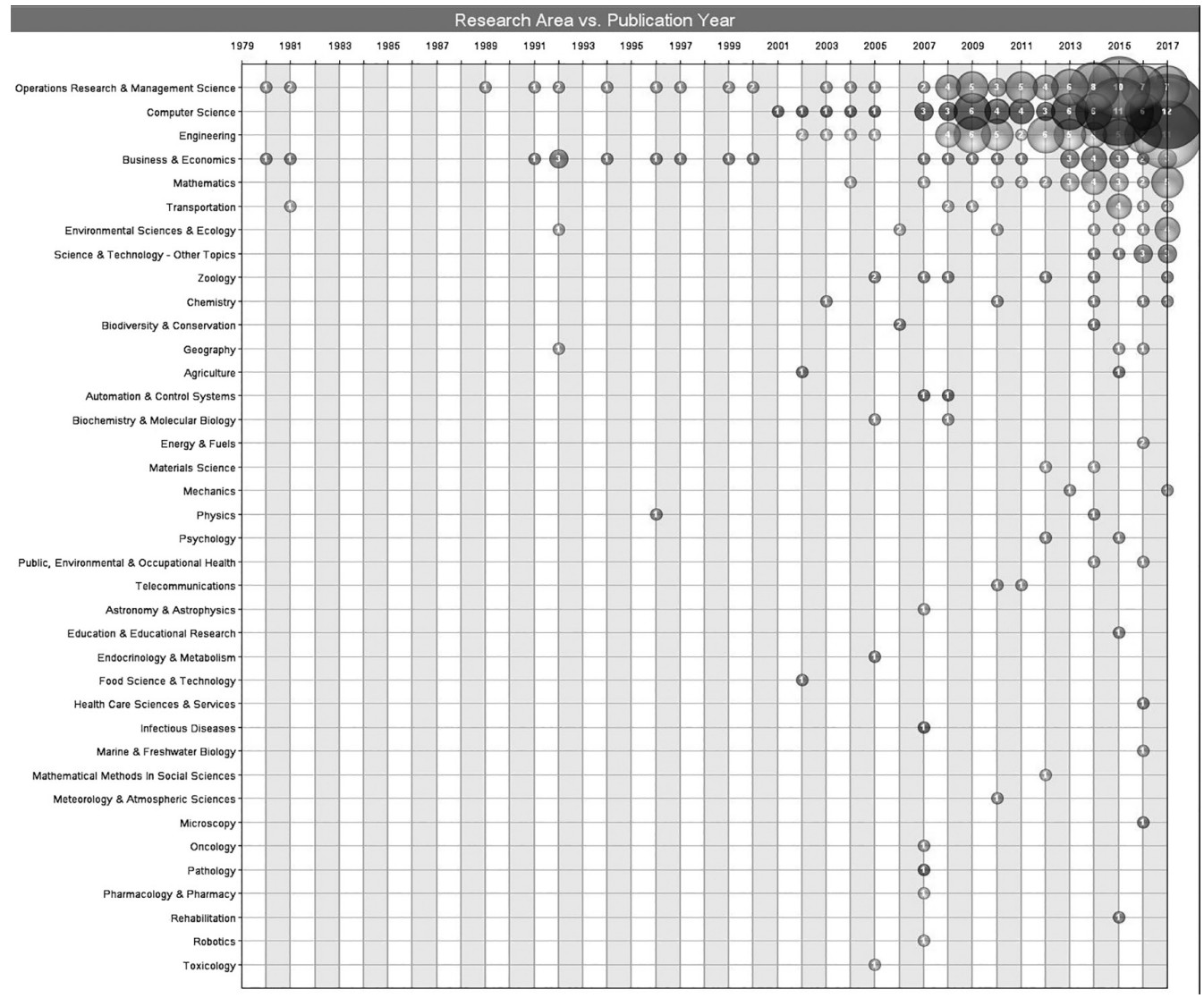

Figure 8 - Evolution of the Brazilian publications of the main areas per year.

2015 (with 4 papers). Besides, there is a recent interest in "Computer Science" and "Engineering" areas, with an increasing volume of paper from 2008. They registered a superior amount of publication in 2017 than the $1^{\text {st }}$ position (12 and 11 articles respectively, against 7 for "Operation Research \& Management Science").

In addition to main areas interested in "facility location", it is possible to identify the most cited articles, see Table 8 . There are, among the top 10 ranking, eight of the main authors presented in Table 5, which reinforce them as the Brazilian references in the area. It is noted that Galvão RD and Lorena LAN has, at least, two articles among the most cited ones.

Comparing the articles of Table 8 with the most relevant ones when considering the whole database, we verified that none of them are among the ten most cited papers published by international researches. The paper in the first place considering the complete database has almost 3 times more citations than Loiola et al. (2007) and the one in the 10th place has approximately $50 \%$ more records than Loiola et al. (2007). Regarding the keywords, approximately 500 different records were found whose the main ones (with, at least, four mentions) are listed in Figure 9. 
Table 8 - The most cited articles with authors filiated to Brazilian institutions.

\begin{tabular}{|c|c|c|c|c|c|}
\hline P. & Authors & Year & Title & Journal & Citations \\
\hline $1^{\text {st }}$ & $\begin{array}{l}\text { Loiola EM; } \\
\text { de Abreu NMM; } \\
\text { Boaventura-Netto PO; } \\
\text { Hahn P; Querido T }\end{array}$ & 2007 & $\begin{array}{l}\text { A survey for the quadratic assign- } \\
\text { ment problem }\end{array}$ & $\begin{array}{l}\text { European Journal of Operational } \\
\text { Research, 176(2): 657-690 }\end{array}$ & 230 \\
\hline $2^{\text {nd }}$ & $\begin{array}{l}\text { Galvão RD; } \\
\text { ReVelle C }\end{array}$ & 1996 & $\begin{array}{l}\text { A Lagrangean heuristic for the } \\
\text { maximal covering location problem }\end{array}$ & \begin{tabular}{|l|} 
European Journal of Operational \\
Research, 88 (1996): 114-123
\end{tabular} & 75 \\
\hline $3^{\text {rd }}$ & $\begin{array}{l}\text { Lorena LAN; } \\
\text { Senne ELF }\end{array}$ & 2004 & $\begin{array}{l}\text { A column generation approach to } \\
\text { capacitated } p \text {-median problems }\end{array}$ & $\begin{array}{l}\text { Computers \& Operations Research, } \\
\text { 31(6): 863-876 }\end{array}$ & 70 \\
\hline $4^{\text {th }}$ & $\begin{array}{l}\text { Silva MR; } \\
\text { Cunha CB }\end{array}$ & 2009 & $\begin{array}{l}\text { New simple and efficient heuristics } \\
\text { for the uncapacitated single alloca- } \\
\text { tion hub location problem }\end{array}$ & $\begin{array}{l}\text { Computers \& Operations Research, } \\
\text { 36: 3152-3165 }\end{array}$ & 48 \\
\hline $5^{\text {th }}$ & Galvão RD & 1980 & $\begin{array}{l}\text { A dual-bounded algorithm for the } \\
p \text {-median problem }\end{array}$ & $\begin{array}{l}\text { Operations Research, 28(5): 1112- } \\
1121\end{array}$ & 47 \\
\hline $6^{\text {th }}$ & $\begin{array}{l}\text { De Camargo RS; } \\
\text { De Miranda GJr; } \\
\text { Luna HP }\end{array}$ & 2008 & $\begin{array}{l}\text { Benders decomposition for the un- } \\
\text { capacitated multiple allocation hub } \\
\text { location problem }\end{array}$ & $\begin{array}{l}\text { Computers \& Operations Research, } \\
\text { 35: 1047-1064 }\end{array}$ & 46 \\
\hline $7^{\text {th }}$ & $\begin{array}{l}\text { Galvão RD; } \\
\text { Espejo LGA; } \\
\text { Boffey B }\end{array}$ & 2000 & $\begin{array}{l}\text { A comparison of Lagrangean and } \\
\text { surrogate relaxations for the maxi- } \\
\text { mal covering location problem }\end{array}$ & $\begin{array}{l}\text { European Journal of Operational } \\
\text { Research, 124: 377-389 }\end{array}$ & 40 \\
\hline \multirow[t]{2}{*}{$8^{\text {th }}$} & $\begin{array}{l}\text { Correa ES; } \\
\text { Steiner MTA; } \\
\text { Freitas AA; } \\
\text { Carnieri C }\end{array}$ & 2004 & $\begin{array}{l}\text { A genetic algorithm for solving a } \\
\text { capacitated } p \text {-median problem }\end{array}$ & $\begin{array}{l}\text { Numerical Algorithms, 35: 373- } \\
388\end{array}$ & 38 \\
\hline & $\begin{array}{l}\text { Lorena LAN; } \\
\text { Lopes F }\end{array}$ & 1994 & $\begin{array}{l}\text { A surrogate heuristic for set cover- } \\
\text { ing problems }\end{array}$ & $\begin{array}{l}\text { European Journal of Operational } \\
\text { Research, 79: } 138-150\end{array}$ & 38 \\
\hline \multirow[t]{2}{*}{$9^{\text {th }}$} & $\begin{array}{l}\text { Chiyoshi F; } \\
\text { Galvão RD }\end{array}$ & 2000 & $\begin{array}{l}\text { A statistical analysis of simulated } \\
\text { annealing applied to the } p \text {-median } \\
\text { problem }\end{array}$ & $\begin{array}{l}\text { Annals of Operations Research, 96: } \\
61-74\end{array}$ & 37 \\
\hline & $\begin{array}{l}\text { Lorena LAN; } \\
\text { Furtado JC }\end{array}$ & 2001 & $\begin{array}{l}\text { Constructive genetic algorithm for } \\
\text { clustering problems }\end{array}$ & $\begin{array}{l}\text { Evolutionary Computation, 9(3): 3, } \\
1-19\end{array}$ & 37 \\
\hline $10^{\text {th }}$ & $\begin{array}{l}\text { Marti R; } \\
\text { Resende MGC; } \\
\text { Ribeiro CC }\end{array}$ & 2013 & $\begin{array}{l}\text { Multi-start methods for combinato- } \\
\text { rial optimization }\end{array}$ & $\begin{array}{l}\text { European Journal of Operational } \\
\text { Research, 226: 1-8 }\end{array}$ & 36 \\
\hline
\end{tabular}

There are keywords associated to the solution techniques such as genetic algorithm, combinatorial optimization and GRASP, although the most relevant are facility location, heuristic and metaheuristic. It should be noted that only 24 keywords were associated, albeit indirectly, with the environmental theme with a mention each. They are: Atlantic forest, biodiversity conservation, biodiversity knowledge, biogas, biomass burning, biomass energy, biomass supply optimization, carbon emissions, carbon footprint, climate change, climatic bias, conservation planning, ecotoxicology, environmental niche models, gas emissions, green supply chain, municipal solid waste, recyclable materials, recycling, solid waste collection, solid waste legislation, solid waste management, water qualiy and waste management.

Besides, there are also two keywords related to the social aspect: social welfare and waste pickers. This finding is consistent with Farahaniet al. (2013) that state that the inclusion of social 


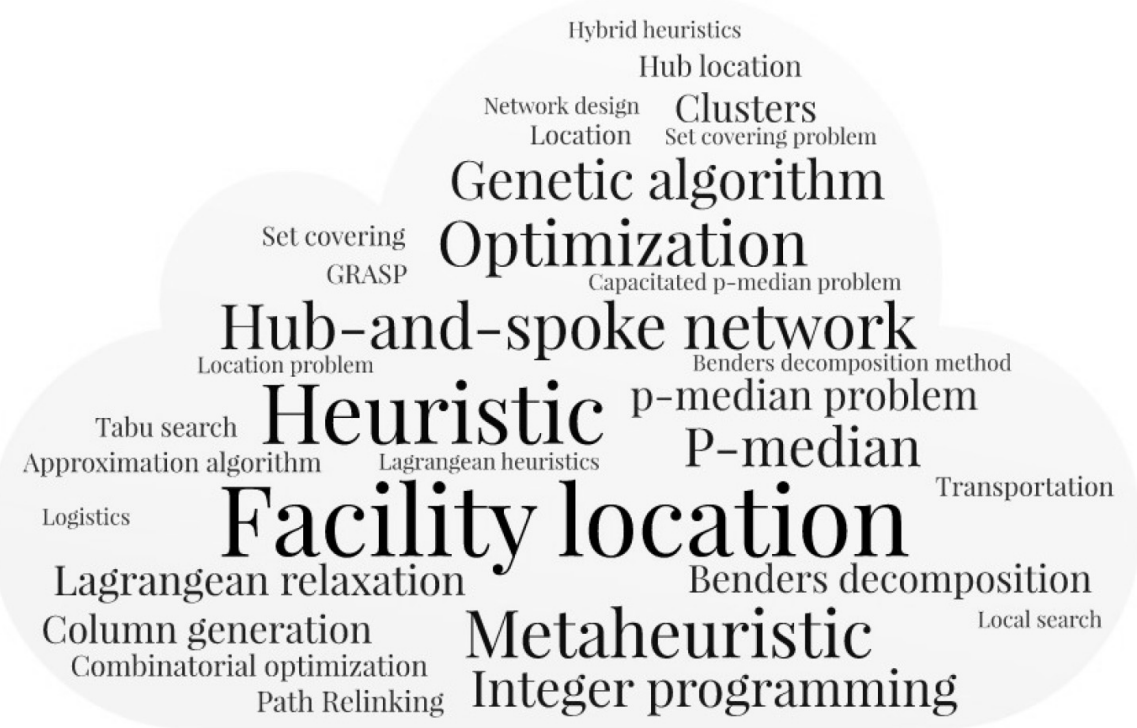

Figure 9 - Main keywords of the Brazilian publications.

and environmental aspects in evaluations is the challenge of this area of research for the coming years. The explicit mention to "sustainability" appears only one time in the keywords list.

\section{FINAL CONSIDERATIONS}

The objectives of this paper were achieved since it was possible to identify the profile of the Brazilian scientific publications on facility location. Besides, it was possible to map the main authors and organizations that are interested in the subject, as well as the collaboration networks, countries and areas of study that stand out.

We noted that publications with Brazilian affiliations account for approximately $2 \%$ of the total database and the interest in "facility location" subject in the Brazilian context is recent, with recurrent records of publications starting in 1999. Nevertheless, the Brazilian volume of publication puts the country among the 15 most relevante ones in the ranking considering the whole database, in front of developed countries such as Portugal and Switzerland.

We also verified that "facility location" is a theme of interest of the scientific community, with predominance of universities (74.6\%), with emphasis on UFMG and UFRJ, with 36 and 24 papers, respectively. However, it is also of governamental (13\%) and business interest (6\%), as INPE and AT\&T are among the eighteen main organizations that publish about this subject (Table 6).

It was verified that the Brazilian collaboration network involves 45 different countries with emphasis on USA with 35 joint papers, followed by United Kingdom with 14 and France with 12. In relation to the authors, there are two consolidated networks. One of them is composed by 
the two main authors (Miranda G and Camargo RS) and includes foreign researchers, and the other is formed by the authors with $2^{\text {nd }}$ and $4^{\text {th }}$ largest volume of articles (Resende MCG and Miyazawa FX, respectively) and twenty other researchers.

As for the organizations, there is a consolidated collaboration network that involves different kind of organizations (national and international), i.e., universities, companies and governmental agencies. It is noteworthy that the three main universities are related to companies, which demonstrate the interest of different types of institution for the theme. Besides, the Top 4 organizations are directely related to international institutions. In addition, there are space for collaboration (including in the company-university-government relationship) in order to foster research on the subject and increase the number of publications.

Regarding the main areas of interest, we highlight "Operations Research \& Management Science", "Computer Science", "Engineering" and "Business \& Economics". It should be noted that, although the "facility location" theme is consolidated in the Operational Research field, we verified that there were only 24 keywords associated to the environmental aspect. This indicates a knowledge gap to be filled in future studies (as already pointed out by Arabani \& Farahani, 2012 and Farahani et al., 2013), which becomes even more relevant with the importance that the sustainability theme has today for all operations and production chains.

Therefore, for future studies, we recommend to investigate the papers that have keywords associated to the environmental theme (considering the complete database) aiming to propose mathematical models that incorporate the environmental dimension with the economic one in the analysis of facility location. In addition, a specific scientometric analysis of these papers could be done in order to understand where the main authors and reference centers are located.

As a limitation, we mention that the study used only one database, not considering publications made in other databases such as Scielo and Scopus. In addition, it is important to highlight that the keywords might influence in the results, therefore, this findings are limited by the keywords chosen and by the database used.

\section{ACKNOWLEDGMENTS}

This research was partly supported by National Council for Scientific and Technological Development (CNPq), Process 307835/2017-0, and by the Carlos Chagas Filho Research Support Foundation (FAPERJ), Process 203.231/2017. This support is gratefully acknowledged. We also thank the Coordination of Improvement of Higher Education Personnel (CAPES) for the doctoral scholarship.

\section{REFERENCES}

[1] AByAZI-SANi R \& GHANBARI R. 2016. An efficient tabu search for solving the uncapacitated single allocation hub location problem. Computers and Industrial Engineering, 93: 99-109. https: // doi.org/10.1016/j.cie.2015.12.028. 
[2] Alizadeh M, Mahdavi I, MahdaVi-Amiri N \& Shiripour S. 2015. A capacitated locationallocation problem with stochastic demands using sub-sources: An empirical study. Applied Soft Computing Journal,34: 551-571. https : / doi.org/10.1016/ j . asoc. 2015.05.020.

[3] Alumur SA, Yaman H \& Kara BY. 2012. Hierarchical multimodal hub location problem with time-definite deliveries. Transportation Research Part E: Logistics and Transportation Review, 48(6): 1107-1120.https: / / doi .org/10.1016/j.tre.2012.04.001.

[4] Alumur S \& KARA BY. 2008. Network hub location problems: The state of the art. European Journal of Operational Research, 190(1): 1-21. https://doi .org/10.1016/j .ejor.2007. 06.008.

[5] Arabani AB \& Farahani RZ. 2012. Facility location dynamics: An overview of classifications and applications. Computers and Industrial Engineering, 62(1): 408-420. https: / / doi .org/ $10.1016 /$ j.cie.2011.09.018.

[6] Ardjmand E, Young Wa, Weckman GR, Bajgiran OS, Aminipour B \& Park N. 2016. Applying genetic algorithm to a new bi-objective stochastic model for transportation, location, and allocation of hazardous materials. Expert Systems with Applications, 51: 49-58. https://doi. org/10.1016/j .eswa.2015.12.036.

[7] Bini LM, Diniz-Filho JAF, Rangel TFlVB, Bastos RP \& Pinto MP. 2006. Challenging Wallacean and Linnean shortfalls: Knowledge gradients and conservation planning in a biodiversity hotspot. Diversity and Distributions, 12(5): 475-482. https://doi.org/10.1111/j . $1366-9516.2006 .00286 . x$.

[8] Borgatti SP, Everett MG \& Freeman LC. 2002. Ucinet for Windows: Software for Social Network Analysis. Harvard, MA: Analytic Technologies.

[9] Campbell JF \& O’Kelly ME. 2012. Twenty-Five Years of Hub Location Research. Transportation Science, 46(2): 153-169. https : / / doi .org/10.1287/trsc.1120.0410.

[10] ChEn X. 2010. The Declining Value of Subscription-based Abstracting and Indexing Services in the New Knowledge Dissemination Era. Serials Review, 36(2): 79-85. https: / / doi . org/10 . 1016/j.serrev.2010.02.010.

[11] Confederação Nacional do Transporte. 2014. Plano CNT de Transporte Logística. Brasília.

[12] Correia I, Nickel S \& Saldanha-DA-Gama F. 2017. A stochastic multi-period capacitated multiple allocation hub location problem: Formulation and inequalities R, 0, 1-13. https : / / doi. org/10.1016/j.omega.2017.01.011.

[13] Coutinho-Rodrigues J, Tralhão L \& Alçada-Almeida L. 2012. Solving a location-routing problem with a multiobjective approach: The design of urban evacuation plans. Journal of Transport Geography, 22: 206-218. https: //doi.org/10.1016/j.jtrangeo.2012.01.006.

[14] CRAINIC TG \& LAPORTE G. 1997. Planning models for freight transportation. European Journal of Operational Research, 97(3): 409-438. https : / / doi .org/10.1016/S0377-2217 (96) 00298-6.

[15] Eskandarpour M, Dejax P, Miemczy J \& PÉTOn O. 2015. Sustainable supply chain network design: An optimization-oriented review. Omega (United Kingdom), 54: 11-32. https : / doi. org/10.1016/j.omega.2015.01.006. 
[16] Farahani RZ, Asgari N, Heidari N, Hosseininia M \& Goh M. 2012. Covering problems in facility location: A review. Computers and Industrial Engineering, 62(1): 368-407. https: //doi.org/10.1016/j.cie.2011.08.020.

[17] Farahani RZ, Hekmatfar M, Arabani AB \& Nikbakhsh E. 2013. Hub location problems: A review of models, classification, solution techniques, and applications. Computers and Industrial Engineering, 64(4): 1096-1109.https://doi.org/10.1016/j .cie.2013.01.012.

[18] Farahani RZ, SteadieSeifi M \& Asgari N. 2010. Multiple criteria facility location problems: A survey. Applied Mathematical Modelling, 34(7): 1689-1709. https: / / doi.org/10 .1016/ j.apm.2009.10.005.

[19] Frade I \& Ribeiro A. 2015. Bike-sharing stations: A maximal covering location approach. Transportation Research Part A: Policy and Practice, 82(December 2014): 216-227. https: //doi.org/10.1016/j.tra.2015.09.014.

[20] FREDRIKSSON A. 2016. Location-allocation of public services - Citizen access, transparency and measurement. A method and evidence from Brazil and Sweden. Socio-Economic Planning Sciences, 1-12. https://doi.org/10.1016/j.seps.2016.09.008.

[21] Gelareh S, Monemi RN \& Nickel S. 2015. Multi-period hub location problems in transportation. Transportation Research Part E: Logistics and Transportation Review, 75: 67-94. https: //doi.org/10.1016/j.tre.2014.12.016.

[22] Governo do Espírito Santo. 2009. Plano Estratégico de Logística e de Transportes do Estado do Espírito Santo - PELT/ES.

[23] Governo do Rio de Janeiro. 2013. Plano Estadual de Logística de Carga do Estado do Rio de Janeiro - PELC/RJ.

[24] Gregolin JÂR, Hoffmann WAM, de Faria Lil, Quoniam L, Queyras J, Fratucci LFDA \& CESAR GA. 2005. Análise da produção científica a partir de indicadores bibliométricos. Indicadores de Ciência, Tecnologia e Inovação em São Paulo 2004, 5.

[25] Guimarães VA, Motta GS, Armond-De-Melo DR, Quintella RH \& Oliveira MA. 2011. O Processo de Inovação Brasileiro: Um Estudo de Caso. In: Congresso de Administração, Inovação e Sociedade (pp. 1-16).

[26] Guimarães VA, Ribeiro GM, do Forte Vl, Lucena A, Leitão Junior AM, Pereira LCSN \& FORNACIARI FA. 2017a. Localização-alocação de centros de integração logística submetidos a demandas par-a-par. Transportes, 25(1): 51. https://doi.org/10.14295/ transportes.v25i1.1027.

[27] Guimarães VA, Ribeiro GM, Forte VL \& Lucena A. 2017b. A location-allocation model for logistics integration centers. International Journal of Transport Economics, XLIV(2): 273-291.

[28] Hajipour V, Fattahi P, Tavana M \& Di Caprio D. 2016. Multi-objective multi-layer congested facility location-allocation problem optimization with Pareto-based meta-heuristics. Applied Mathematical Modelling, 40(7-8): 4948-4969. https : / doi .org/10.1016/j . apm. 2015. 12.013.

[29] Hamadani AZ, Ardakan MA, Rezvan T \& Honarmandian MM. 2013. Location-allocation problem for intra-transportation system in a big company by using meta-heuristic algorithm. SocioEconomic Planning Sciences, 47: 309-317. 
[30] Harris I, MUMFord CL \& NAIM MM. 2014. A hybrid multi-objective approach to capacitated facility location with flexible store allocation for green logistics modeling. Transportation Research Part E: Logistics and Transportation Review, 66: 1-22. https : / doi .org/10.1016/j . tre. 2014.01 .010$.

[31] He Y, Wu T, Zhang C \& Liang Z. 2015. An improved MIP heuristic for the intermodal hub location problem. Omega, 57: 203-211.

[32] IshfaQ R \& Sox CR. 2011. Hub location-allocation in intermodal logistic networks. European Journal of Operational Research, 210(2): 213-230. https: / / doi .org/10.1016/j .ejor. 2010.09 .017$.

[33] Klose A \& DREXL A. 2005. Facility location models for distribution system design. European Journal of Operational Research, 162(1): 4-29. https: //doi.org/10.1016/j .ejor.2003. 10.031.

[34] Lin CC, Chiang YI \& Lin SW. 2014. Efficient model and heuristic for the intermodal terminal location problem. Computers and Operations Research, 51: 41-51. https: / / do i . org/10 . $1016 / j$. cor.2014.05.004.

[35] Lin CC \& LiN SW. 2016. Two-stage approach to the intermodal terminal location problem. Computers and Operations Research, 67: 113-119. https : / / doi .org/10.1016/j . cor.2015. 09.009.

[36] LiU C \& GUi Q. 2016. Mapping intellectual structures and dynamics of transport geography research: a scientometric overview from 1982 to 2014. Scientometrics, 109(1): 159-184. https: //doi.org/10.1007/s11192-016-2045-8.

[37] Loiola EM, de Abreu nMm, Boaventura-Netto PO, Hahn P \& Querido T. 2007. A survey for the quadratic assignment problem. European Journal of Operational Research, 176(2): 657-690.https://doi.org/10.1016/j.ejor.2005.09.032.

[38] LoRENA LAN \& SENNE ELF. 2004. A column generation approach to capacitated p-median problems. Computers and Operations Research, 31(6): 863-876. https://doi.org/10.1016/ S0305-0548 (03) 00039-X.

[39] Lorena LAN \& Furtado JC. 2001. Constructive Genetic Algorithm for Clustering Problems. Evolutionary Computation, 9(3), 309327. https://doi.org/10.1162/106365601750406019

[40] Meisel F, Kirschstein T \& Bierwirth C. 2013. Integrated production and intermodal transportation planning in large scale production-distribution-networks. Transportation Research Part E: Logistics and Transportation Review, 60:62-78. https://doi.org/10.1016/j.tre. 2013.10 .003$.

[41] Melo MT, Nickel S \& Saldanha-Da-Gama F. 2009. Facility location and supply chain management - A review. European Journal of Operational Research, 196(2): 401-412. https: //doi.org/10.1016/j.ejor.2008.05.007.

[42] Menezes RC \& Pizzolato ND. 2014. Locating public schools in fast expanding areas: application of the capacitated p-median and maximal covering location models. Pesquisa Operacional, 34(2): 301-317.https://dx.doi.org/10.1590/0101-7438.2014.034.02.0301.

[43] MotTa GS \& Quintella RH. 2012. Assessment of non-financial criteria in the selection of investment projects for seed capital funding: The contribution of scientometrics and patentometrics. Journal of Technology Management and Innovation, 7(3): 172-193. 
[44] MT - Ministério dos Transportes. 2009. Relatório Executivo PNLT. Brasília.

[45] MT - Ministério dos Transportes. 2007. Plano Nacional de Logística e Transportes: Sumário executivo. Brasília.

[46] MT - Ministério dos Transportes. 2012. Projeto de reavaliação de estimativas e metas do PNLT: Relatório Final. Brasília.

[47] Özceylan E, Uslu A, Erbaş M, Çetinkaya C \& Kürşat S. 2017. Optimizing the locationallocation problem of pharmacy warehouses: A case study in Gaziantep, 7(1): 117-129.

[48] Pamucar D, Vasin L, Atanaskovic P \& Milicic M. 2016. Planning the City Logistics Terminal Location by Applying the Green $p$-Median Model and Type-2 Neurofuzzy Network. Computational Intelligence and Neuroscience, 2016(January). https://doi.org/10.1155/2016/ 6972818.

[49] Paul JA \& MAcDonald L. 2016. Location and capacity allocations decisions to mitigate the impacts of unexpected disasters. European Journal of Operational Research, 251(1): 252-263. https://doi.org/10.1016/j.ejor.2015.10.028.

[50] Santos BF, Limbourg S \& CARreira JS. 2015. The impact of transport policies on railroad intermodal freight competitiveness - The case of Belgium. Transportation Research Part D: Transport and Environment, 34: 230-244. https: // doi .org/10.1016/j .trd.2014.10.015.

[51] SPNT - Secretaria de Política Nacional de Transportes. 2016. Centros de integração logística.

[52] TAGUL. 2017. Word Cloud. Available at: https://wordart.com/create.

[53] The Vantage Point. 2016. Vantage Point - Version 9. Search Technology, Inc. (www. theVantagePoint.com)

[54] Thomson Reuters. 2016. Web of ScienceTMTodas as bases de dados.

[55] Ulukan Z \& DemircioǦlu E. 2015. A Survey of Discrete Facility Location Problems. International Journal of Social, Behavioral, Educational, Economic, Business and Industrial Engineering, 9(7): 2450-2455.

[56] UpChurch C \& Kuby M. 2010. Comparing the p-median and flow-refueling models for locating alternative-fuel stations. Journal of Transport Geography, 18(6): 750-758. https : / / doi .org/ $10.1016 / j$.jtrangeo.2010.06.015.

[57] WEN M, QIN Z, KANG R \& YANG Y. 2015. The capacitated facility location-allocation problem under uncertain environment. Journal of Intelligent and Fuzzy Systems, 29(5): 2217-2226. https: //doi.org/10.3233/IFS-151697.

[58] Yu B, Zhu H, Cai W, Ma N, Kuang Q \& Yao B. 2013. Two-phase optimization approach to transit hub location - the case of Dalian. Journal of Transport Geography, 33: 62-71. https: //doi.org/10.1016/j.jtrangeo.2013.09.008.

[59] Zahiri B, Tavak Koli-Moghaddam R \& Pishvaee MS. 2014. A robust possibilistic programming approach to multi-period location-allocation of organ transplant centers under uncertainty. Computers and Industrial Engineering, 74(1): 139-148. https://doi.org/10.1016/j.cie. 2014.05 .008$. 
[60] Zhang W, CaO K, LiU S \& Huang B. 2016. A multi-objective optimization approach for health-care facility location-allocation problems in highly developed cities such as Hong Kong. Computers, Environment and Urban Systems, 59: 220-230. https: // doi.org/10.1016/ j . compenvurbsys.2016.07.001.

[61] Zhu Y, Du Q, Tian F, Ren F, Liang S \& Chen Y. 2016. Location Optimization Using a Hierarchical Location-Allocation Model for Trauma Centers in Shenzhen, China. ISPRS International Journal of Geo-Information, 5(10): 190. https: / / doi .org/10 .3390/ijgi5100190. 